\title{
Customer Loyalty Program and Retention Relationship
}

\section{Pratik Pal Bariha}

Symbiosis Institute of Business Management, Bengaluru in partial fulfilment of the course "Summer Internship Program" for the award of the degree of Master of Business Administration

\begin{abstract}
The aim of this study is to achieve the understanding on the different types of loyalty programs and their impact on the customers buying decision, patterns, behavior and ultimately the impact of their retention towards the brand or product in a long term.

To achieve the conclusion, different research papers with the different surveys and geographic location were taken with random data. The participants in the surveys were primarily students and people from age group between 20-45 years. The finding from the study clearly shows that there is a significant impact of customer retention on different types of loyalty program.
\end{abstract}

Keywords

Customers, Customer retention, Loyalty program, Monetary program, Types of loyalty programs, Rewards.

Article Received: 10 August 2020, Revised: 25 October 2020, Accepted: 18 November 2020

\section{Introduction}

Loyalty programs have always been a powerful method for establishing and maintaining relationship with the customers. The introduction of loyalty program can bring benefits to the organization as well as the customers.

Organizations: For the success of a company it is particularly important for them to maintain a healthy relationship with the and customer base. Creating new customer base or bringing up more customers can be expensive as compared to keeping the existing customers. Companies try to draw customers who would be loyal towards the company for the lifetime because when the company has a strong relationship with the customers it can virtually makes the customers forget about the competitors.

Customers: From the customers perception the loyalty programs are perceived as a reward from the company which encourages the customers to be loyal for the brand or encourages them to go to the same brand again and again. Customers are encouraged to do this because it helps them in better decision making and to get better consistency in their decision.

\section{Theoretical framework}

\section{Loyalty Program}

Loyalty programs are the rewards provided to the customers to make them feel special and more satisfied towards the brand which influences the buying behavior and decisions of the customers and can be crucially beneficial to the firm. Company can provide rewards to the customer who do regular business with the firm by providing them special discounts, early access to the product, exclusive offers etc. This helps in getting the information from the customer such as likes, trends, satisfaction level, which can further be analyzed by the company to make future decision based on the previous information provided by the customers. This way the company already has the possible outcomes of their future decision and which can be tailored anytime and is very less expensive because the company does not have to collect data from any other sources.

On the other hands the customers receive discounts, exclusive sale offer, monetary reward, coupons etc. by participating in the loyalty program which is mostly free or can be opted with nominal upfront joining fees.

Customer Loyalty: When the customer prefers to choose one brand or product over the competitor because of the satisfaction provided by that brand, it is called customer loyalty. Customer loyalty is resulted by the positive previous experiences from the brand which draws them to the same brand again and again it may be caused y various factors i.e. Quality, service, availability, rewards, after sales services etc. These factors help in bringing the customers again and again and provide the satisfaction to the customers that they are choosing the right brand regardless of the fact that other brand may offer better quality product.

Customer Retention: When a company manages to keep its customer and making them come to them again and again and choosing them over all the competitors in the marketplace by providing better value to the customer is termed as customer retention. Customer retention is very crucial for the growth of the business and customer loyalty can help the business to retain the customers.

To retain the most valuable customers the company needs to put together the customers emotions and psychology with the reputation of the company this will help to establish a emotional and mental bond with the customers without which the retention is almost impossible.

The most focused group in terms of customers are the occasional customers who purchase very rarely, because unlike the new customers these occasional customers are already aware of the products and services on offerings and the quality of the offerings and then choose to come to store and make decision since they are already aware about the company and the products it is easier to convince them to choose the brand over the competitors by providing some sort of values which is missing by the competitors.

Customer retention is mostly concerned on the customers experience because these are the customers who will 
recommend the brand further to their families and friends and help in marketing via word of mouth.

\section{Dimensions of Loyalty programs}

Different organizations offer different types of loyalty programs for their customers to keep them engaged with their business. Organizations choose to opt for the loyalty programs based on the type of the industry they deal in as well as the preference and patterns of customers decisions. In retail industry loyalty programs and membership are used extensively as a part of marketing effort as these could be potentially beneficial to the company.

Examples: - Loyalty cards, reward card, club cards, membership cards etc.

Tier System- As the name suggests these programs offer the customers to climb up the ladder or tier by repeatedly making the purchases and increasing their tier. In such program's customers receive more valuable rewards when they reach higher tiers which encourages them to make frequent or high valued purchases.

Point system- In such programs the customers earn some points every time they make purchase which can later be converted by redeeming the points into some sorts of gifts, discounts which is already mentioned in the program.

V.I.P Benefits: Customers are charged onetime fees to become V.I.P. Membership with which they can avail various offers or facilities which are exclusive for the V.I.P. customers. This way the company increase the satisfaction of the customers by providing more and more facilities to them.

These types of programs are concentrated on the relatively regular customers who are anyways using the products or services.

Example: Airline Industry, Service industry.

Frequent Buyers: Companies encourage the customers to make continue purchases so that the customer reaches a threshold limit to get the offer this way company makes the customer make more purchases. It helps in making the sales higher and customer loyalty over time.

Gifts: Company provides gift vouchers which may contain additional offers or discounts but are redeemable one when the customer makes any purchase and spend a specific amount.

Bundle goods: Providing similar goods or goods from the same brand so that customer may feel more valuable and confident with doing purchases from the retailer.

Extended Returns: Offering a return policy for extended duration for the loyal customers who make purchases very often.

Non-Monetary programs: Companies try to make the customer feel more valuable by different ways like solving the issues quickly, listening to the suggestions, providing better services.

After Sales: Some retailers provide extra warranty or after sale service for their premium customers.

These offers make the customers feel more valuable and encourage them to spend often in the company.

\section{Benefits of loyalty programs}

i. Cost: Less cost to serve the customers who are already loyal for the company.

ii. Expenditure: Loyal customers have the tendency to spend more on the company as compared to the occasional customers because the perceived value attached with it.

iii. Retention: Retention of loyal customers is comparatively less expensive.

iv. Sensitivity: Loyal customers have less sensitivity towards the pricing of the brand or product because the association of the value.

v. Loyal customers tend to purchase relatively more products.

Overall the loyalty programs creates a win-win situation for both the organization and the customers as the organization makes profit from the loyal customers and customer retention by less investment and less cost application at the same time providing valued service and products to the customers where as the customers feels confident and more valued by doing business with organization by getting extra benefits and rewards in exchange of their purchases.

The organization will not have to extensive and expensive surveys and researches all the time for new or improved products which could result for them in saving the cost and making the product cheaper and providing the products at cheaper rates in return the customers can feel important and valued by the company that is doing all these for their customers.

Significance in different industries: As the significance goes, different industries caters to different types of customers with different needs and wants which makes it obvious for the industries to come up with the different strategies, plans and Programs in terms of retention of those customers.

Life style Industries: Since lifestyle and clothing industries see the coming and loss of customers almost every day where the loyalty of the customers is also effected by very small factors these industries needs to come up with the plans very carefully which should also be focused specifically on different segments of the customers.

Example: Not all customers are interested in discounts there may be customers who may chose rewards over the discounts offered if the program is not focused on the specific group of people it might spoil the whole strategy.

Aviation Industry: People do not travel as frequently as they do the daily shopping also the expenditure is also high from the customers perspective hence these industry usally focus on improving the service quality rather than providing huge discounts and adds few non-monetary rewards such as lounge access or frequent flyer bonuses.

Daily needs and grocery: This industry is very sensitive to pricing and customers chose to not spend a lot on these purchases and mostly seek discounts and monetary-rewards over the service.

Gap There are a lot of researches already available on the customer loyalty and retention but most of them are limited to a certain geographic location and since different location has different culture and trends, the findings from that particular location cannot be applied universally.

Researches are also very much focused on the specific age group and demographics which again can be hindrance in terms of applications because different demographic may 
not want the same things and same type of rewards or loyalty programs. This is mostly affected by

$\begin{array}{ll}\text { I. } & \text { Age } \\ \text { II. } & \text { Gender } \\ \text { III. } & \text { Income } \\ \text { IV. } & \text { Lifestyle } \\ \text { V. } & \text { Standard of living } \\ \text { VI. } & \text { Trends }\end{array}$

Data collected in these researches are many times manipulated to achieve the desired results which questions the authenticity of the research so the researchers needs to be honest and publish the results as it was achieved without any manipulation of any sort.

Questionnaire - Mostly questionnaires are provided to the customers for their reviews and feedbacks for the purpose of research but most of the researches are done by the big brands or researchers sponsored by these brands in such cases the brand or researcher usually ask questions specific to the brand or the products or services offered by these brands which limits the use of such researches to specific category of brands or the industry.

Simplicity - The questions asked by the researchers are sometimes over simplified which is a good thing in customers perspective but it may result in lack of very minute but important information about the customers.

Hence the questions asked from the customers needs to be as simple as it should not repel the customers and at the same time it should be efficient enough to collect all the required information and the information that could potentially be used for further researches.

Partnership - Sometimes two or more brands come together to offer loyalty programs to the customers where the customers or the members of loyalty program can earn or redeem rewards from participating brands in such cases the brand value of the participating brands comes in picture which needs to be studied and or evaluated effectively.

Entry or Exit- In such cases the entry or exit of the partners should also be addressed as to how it might affect the overall joint loyalty program experience for the customers and how it will impact on the same.

Categorize - Use of different type of loyalty programs for different business because same type of loyalty program may not be suitable for different types of business hence the researchers and the brands/firms first need to identify the most effective type of program to offer to their customers before the research. This can be done by referring previous researches on the similar fields.

Privacy - Since most of the researches are done to find out trends and to make strategies based on the same and also to be used as reference for further studies the members that took part in the research or the program should be made aware about the studies the information provided by them may be used for further studies. Members may not want to share their information to more than one research or programs in such cases it is a responsibility of the researchers to maintain their ethics and or exclude the information of such members from the study. Companies some times sell the information of their customers to other companies to earn profits which needs to be stopped until or unless the members or customers are aware of it or give permission for their individual information to be shared.
Complexity Some times the programs are to complicated for the common customers to understand which leads to false or wrong or unintentional feedback from the customers and this could result in achieving incorrect information from the customers.

Example- Unnecessary rewards, Difficult to understand tier system.

Time Consuming - Some researches are very time consuming and dull which makes the participants to lose interest in the program and hence researcher should always come up with the strategies to keep the participants engaged in the program. This is also true for the members of loyalty programs where it takes very long time period to gain or redeem the rewards in such cases also customers loose interest and opt for other loyalty programs this should always be analyzed before implementing any loyalty programs.

\section{Literature Review}

(Titles Of the papers are given in the reference page at the end)

Hoffman-Kohlmeyer came to a conclusion that an effective loyalty program comprises of both effective and financial components. It is less likely that only monetary benefits will guarantee the return of the customers or retention of the customers. The reward program can be very important in terms of source of customers information and customers database and the data that is collected from these programs should be used to create an effective marketing strategy. Meanwhile it is also very important to maintain the privacy and secrecy of the customers and it is a sole responsibility of the brand/firm because this defines that how much the customers trust the brand/firm. It has also been analyzed by the researchers that the loyalty programs are proved to be very profitable because they are created to retain the existing customers and it is less expensive for a company to retain or serve the existing customers than to attract new ones.

Mathur has concluded that in India there is a tough competition among companies in organized retailing business and in order to survive in such completion, brands must understand their customers thoroughly to create an effective and strong relationship with their customers. This automatically results in development and creation of new loyalty programs which holds attractive tangible and intangible benefits for their customers.

Zakaria concluded that a significant and positive relationship between customer satisfaction and loyalty program already exists for JUSCO AEON. The results of his research clearly provide insights that gifts redemption, rebate gift vouchers, shopping partners program, special price for members etc. significantly increase the influence the customer satisfaction. The research also concludes that the magazines and insurance coverage does not have any significant influence on the customer satisfaction, study also provides information that the customers who are happened to be loyal to JUSCO AEON are also loyal to other retailers as well.

Mayor came to the conclusion that loyalty programs play a significant role in creating and maintaining loyalty from the customers. Given the current scenario we can not rely 
completely on any random and rigid loyalty program, we can see that in case of jet airways where it had to rethink and redesign a complete new one which had flexibility. This new flexible program resulted in positive relationship between customer longevity and repeat sales. Company was well aware about the fact that bringing up a new program and providing training to the employees will consume more time and will be more expensive. Referrals and feedback that is provided by the customers helped in bringing new customers. All aspects of demographics should be taken care of at the time of making new loyalty program such as age, gender etc. at the same time company must have some differentiating factors in their loyalty programs and then the most important factor that company must do a thorough analysis on the revenue and cost involved in each programs before implementing the it.

Gupta \& Srinivasan Concluded that all the brands no a day use some sort of loyalty programs to retain and attract their customers and profitability. This programs not only help in maintaining the profitability but also in identification of likes-dislikes, habits and purchasing behaviors so that they could serve them better with the products they like or dislike this helps in increasing the satisfaction level of customers.

The brands included in the research - Van Heusen,

Pantaloons, Westside, and their loyalty programs and what differentiated them from each other.

Gomez, Arranz, \& Cillan Concluded that all the loyalty programs gets stronger and more effective in long run. Their research was primarily focused on the grocery retail industry where we can see the highest numbers of loyalty programs. In the study itt was found that the customers who are members of any loyalty program display higher commitment, positive attitude, trust and satisfaction as compared to the nonmembers. In such companies where they offer loyalty programs enjoy higher behavioral loyalty as compared to the ones who do not offer such loyalty programs.

\section{Hypotheses}

H1 - Loyalty Programs does not lead to customer retention. $\mathrm{H} 2$ - Customer is fully aware of the benefits of the loyalty program.

Proposed Research model

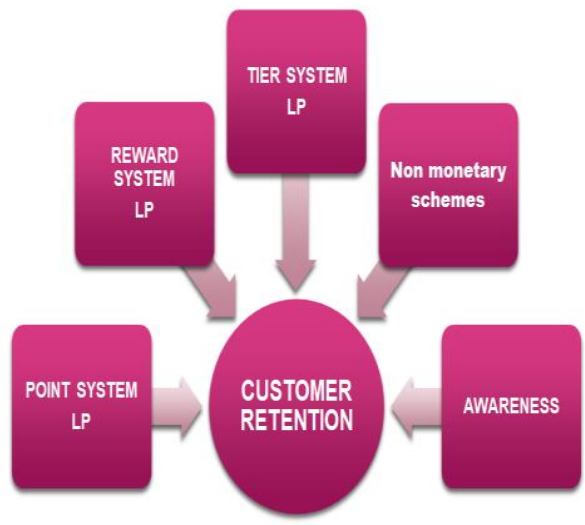

\section{Statistical Analysis}

\section{Test for normal distribution}

It can be determined that the data is normally distributed by descriptive statistics. The skewness, kurtosis, S.D. help us determine that the data is normally distributed

\begin{tabular}{|c|c|c|c|c|c|c|c|c|c|c|c|c|}
\hline A & B & c & D & $\mathrm{E}$ & $\mathrm{F}$ & G & $\mathrm{H}$ & I & $\mathrm{J}$ & $\mathrm{K}$ & L & M \\
\hline $\begin{array}{l}\text { Have you ever } \\
\text { missed the } \\
\text { opportunity to } \\
\text { use your reward } \\
\text { or points? }\end{array}$ & $\begin{array}{l}\text { r Have you eve } \\
\text { missed th } \\
\text { opportunity t } \\
\text { ose you } \\
\text { ? reward } \\
\text { points? }\end{array}$ & $\begin{array}{l}\text { ver Are you } \\
\text { the fully aware } \\
\text { to of your } \\
\text { our loyalty } \\
\text { or program? }\end{array}$ & $\begin{array}{l}\text { Are you } \\
\text { fully aware } \\
\text { of your } \\
\text { loyalty } \\
\text { program? }\end{array}$ & $\begin{array}{l}\text { Does a good } \\
\text { loyalty program } \\
\text { r encourage you } \\
\text { to go the the } \\
\text { same store } \\
\text { offering it? }\end{array}$ & $\begin{array}{l}\text { Does a good } \\
\text { loyalty program } \\
\text { encourage you to } \\
\text { go the the same } \\
\text { store offering it? }\end{array}$ & $\begin{array}{l}\text { d Does loyalty } \\
\text { program } \\
\text { o affect your } \\
\text { e buying } \\
\text { ? behavior? }\end{array}$ & $\begin{array}{c}\text { Does } \\
\text { loyalty } \\
\text { program } \\
\text { affect your } \\
\text { buying } \\
\text { behavior? }\end{array}$ & & & & & \\
\hline Yes & & 1 No & 0 & Yes & & 1 No & 0 & Colum & & & Colun & \\
\hline Yes & & 1 Yes & & 1 Yes & & 1 Yes & 1 & & & & & \\
\hline Yes & & 1 No & & Yes & & 1 No & & Mean & 0.7 & & Mean & 0.675 \\
\hline No & & 0 Yes & & No & & 0 No & 0 & Standard Error & 0.073379939 & & Standard Error & 0.075 \\
\hline No & & 0 Yes & & 1 Yes & & 1 Yes & & Median & 1 & & Median & 1 \\
\hline No & & 0 Yes & & 1 Yes & & 1 Yes & 1 & Mode & 1 & & Mode & 1 \\
\hline Yes & & 1 No & & Yes & & 1 Yes & 1 & Standard Deviation & 0.464095481 & & Standard Deviation & 0.474341649 \\
\hline Yes & & 1 Yes & & Yes & & 1 Yes & 1 & Sample Variance & 0.215384615 & & Sample Variance & 0.225 \\
\hline Yes & & 1 No & & Yes & & 1 Yes & 1 & \begin{tabular}{|l} 
Kurtosis \\
\end{tabular} & \begin{tabular}{|c|}
-1.241617557 \\
\end{tabular} & & \begin{tabular}{|l} 
Kurtosis \\
\end{tabular} & -1.473051999 \\
\hline No & & 0 No & & No & & 0 Yes & 1 & Skewness & -0.907254324 & & Skewness & -0.776699776 \\
\hline Yes & & 1 Yes & & No & & 0 Yes & 1 & \begin{tabular}{|l|} 
Range \\
\end{tabular} & 1 & & \begin{tabular}{|l|} 
Range \\
\end{tabular} & 1 \\
\hline Yes & & 1 Yes & & 1 Yes & & 1 Yes & 1 & Minimum & 0 & & Minimum & 0 \\
\hline No & & 0 Yes & & Yes & & 1 Yes & 1 & Maximum & 1 & & Maximum & 1 \\
\hline Yes & & 1 No & & Yes & & 1 Yes & 1 & Sum & 28 & & Sum & 27 \\
\hline Yes & & 1 No & 0 & Yes & & 1 Yes & 1 & Count & 40 & & Count & 40 \\
\hline No & & 0 No & 0 & Yes & & 1 Yes & 1 & & & & & \\
\hline Yes & & 1 No & 0 & Yes & & 1 Yes & 1 & & & & & \\
\hline No & & 0 Yes & & Yes & & 1 No & 0 & & & & & \\
\hline Yes & & 1 No & & No & & 0 No & 0 & & & & & \\
\hline No & & 0 No & & No & & 0 Yes & 1 & & & & & \\
\hline Yes & & 1 No & 0 & Yes & & 1 Yes & 1 & & & & & \\
\hline Yes & & 1 Yes & & Yes & & 1 Yes & 1 & & & & & \\
\hline Yes & & 1 No & 0 & Yes & & 1 Yes & 1 & & & & & \\
\hline No & & 0 Yes & & No & & 0 Yes & 1 & & & & & \\
\hline Yes & & 1 No & 0 & Yes & & 1 Yes & 1 & & & & & \\
\hline Yes & & 1 No & 0 & Yes & & 1 No & 0 & Colum & & & Colur & \\
\hline Yes & & 1 No & 0 & Yes & & 1 No & 0 & & & & & \\
\hline Yes & & 1 No & & No & & 0 No & & Mean & 0.325 & & Mean & 0.675 \\
\hline No & & 0 No & 0 & Yes & & 1 Yes & 1 & Standard Error & 0.075 & & Standard Error & 0.075 \\
\hline Yes & & 1 No & 0 & Yes & & 1 Yes & 1 & Median & 0 & & Median & \\
\hline No & & 0 No & & No & & 0 Yes & & Mode & 0 & & Mode & \\
\hline Yes & & 1 No & & No & & 0 No & 0 & Standard Deviation & 0.474341649 & & Standard Deviation & 0.474341649 \\
\hline Yes & & 1 Yes & & 1 No & & 0 Yes & 1 & Sample Variance & 0.225 & & Sample Variance & 0.225 \\
\hline Yes & & 1 Yes & & No & & 0 No & 0 & Kurtosis & $\begin{array}{l}-1.473051999 \\
\end{array}$ & & Kurtosis & -1.473051999 \\
\hline Yes & & 1 No & & No & & 0 No & 0 & Skewness & 0.776699776 & & Skewness & -0.776699776 \\
\hline Yes & & 1 No & & No & & 0 No & 0 & Range & 1 & & Range & 1 \\
\hline Yes & & 1 No & 0 & Yes & & 1 No & 0 & Minimum & 0 & & Minimum & 0 \\
\hline Yes & & 1 No & 0 & Yes & & 1 Yes & 1 & Maximum & 1 & & Maximum & 1 \\
\hline No & & 0 No & 0 & Yes & & 1 Yes & & Sum & 13 & & Sum & 27 \\
\hline Yes & & 1 No & 0 & Yes & & 1 Yes & & Count & 40 & & Count & 40 \\
\hline
\end{tabular}




\section{ANOVA Test}

Dependent Variable: Customer Retention

Independent Variable: Reward Point rewards, Point System,

Tier system

\begin{tabular}{|c|c|c|c|c|c|}
\hline ANOVA & & & & & \\
\hline & $d f$ & SS & $M S$ & $F$ & Significance $F$ \\
\hline Regression & 1 & 0.525 & 0.525 & 2.418181818 & 0.128224212 \\
\hline Residual & 38 & 8.25 & 0.217105263 & & \\
\hline Total & 39 & 8.775 & & & \\
\hline \multicolumn{6}{|l|}{ ANOVA } \\
\hline & $d f$ & SS & $M S$ & $F$ & Significance $F$ \\
\hline Regression & 1 & 0.877564103 & 0.877564103 & 4.222564935 & 0.04681188 \\
\hline Residual & 38 & 7.897435897 & 0.20782726 & & \\
\hline Total & 39 & 8.775 & & & \\
\hline
\end{tabular}

From the above test, it can be seen that Multiple Regression can be used for further data analysis

\section{Multiple Regression Model}

Multiple regression analysis was used to examine the effect of loyalty programs on customer retention. It can be seen from the high R square and high Adjusted R Square that the regression model is successful and the data is relevant.

\begin{tabular}{|c|c|c|c|c|c|c|c|c|}
\hline \multicolumn{9}{|l|}{ SUMMARY OUTPUT } \\
\hline \multicolumn{9}{|c|}{ Regression Statistics } \\
\hline Mutiple R & 0.244599795 & & & & & & & \\
\hline R Square & 0.086537947 & & & & & & & \\
\hline Adjusted R Square & 0.091635748 & & & & & & & \\
\hline Standard Error & 0.465945558 & & & & & & & \\
\hline Observations & 40 & & & & & & & \\
\hline \multicolumn{9}{|l|}{ ANOVA } \\
\hline & $d f$ & SS & MS & $F$ & Significance $F$ & & & \\
\hline Regression & 1 & 0.525 & 0.525 & 2.418181818 & 0.128224212 & & & \\
\hline Residual & 38 & 8.25 & 0.217105263 & & & & & \\
\hline \multirow[t]{2}{*}{ Total } & 39 & 8.775 & & & & & & \\
\hline & Coefficients & Standard Error & tStat & P-value & Lower 95\% & Upper 95\% & Lower $95.0 \%$ & Upper 95.0\% \\
\hline Intercept & 0.5 & 0.134506897 & 3.717281509 & 0.000646929 & 0.227705023 & 0.772294977 & 0.227705023 & 0.772294977 \\
\hline X Variable 1 & -0.25 & 0.160766491 & -1.555050423 & 0.036489579 & -0.575454746 & 0.075454746 & -0.575454746 & 0.075454746 \\
\hline
\end{tabular}

\section{Conclusion}

As indicated by the results of the current examination, all types of loyalty schemes are helpful and significant in retaining customers. That concludes retaining customers is profitable because of loyalty schemes. A strong impact was observed for all types of loyalty schemes (Tier reward program, point program and reward system) on retaining customers.

\section{Suggestions}

Marketers need to innovate loyalty programs that reverberate with customer's shopping habit and lifestyle, in order to increase customer retention and develop customer loyalty by creating a lifetime customer. To achieve this goal, recommendations are as follow:-

1. Marketers must focus on loyalty programs that have a high impact on customer retention Especially the Point system and Tier system reward.

2. Retailers need to invest in research for developing innovative techniques to develop and upgrade their loyalty schemes.

3. Marketers and companies also look into the aspect of awareness and make people more aware to increase loyalty program success because of low awareness surrounding loyalty programs

4. Develop loyalty programs to attract millennials that fit their needs as Millenials typically spend much more than the population.

5. Develop a transparent feedback system and take feedback from the consumers and then incorporate those insights into the loyalty program.

6. Diversify loyalty programs to attract customers of different demography and increase market share.

7. Keep the customers informed about the benefits and rewards they can avail from a particular loyalty program and hence increase the awareness.

The most trending loyalty programs now a days are

1. Frequent flyers: Number of travelers is increasing everyday which provides a huge scope for the aviation industry and its growth and as more people are now travelling quality of service may be decreased so the industry needs to find the solution for overcoming this issue without being too expensive for the customers.

2. Tier System: In case of lifestyle retail stores, this industry has always seen improvements in all aspects but now after the covid-19 pandemic the industry can improve its service quality even more and provide the customers a sense of safety and confidence to go and purchase there.

3. Researchers should be exposed to more areas and include larger population to come up with reliable solution and information which could be applied universally.

All the industry should increase their safety standards specially the retail industries so that the customers may feel more valued and confident as well as feeling the value gains to be increased which impacts the confidence level of these customers in the company.

\section{Reference}

[1] https://www.researchgate.net/publication/3 31833326_The_Impact_of_Customer_Loy alty_Programs_on_Customer_Retention

[2] https://www.researchgate.net/publication/3 34046955_Analysis_of_key_indicators_th at_affect_the_expected_benefit_of_custom ers_when_using_loyalty_cards

[3] https://www.researchgate.net/publication/3 20865813_The_role_of_a_CustomerOriented_Service_Culture_in_influencing _Customer_Retention_in_the_Hotel_Indus try

[4] https://hbr.org/1995/05/do-rewards-reallycreate-loyalty

[5] https://www.annexcloud.com/blog/10benefits-implementing-customer-loyaltyprogram/ 
[6] https://www.sciencedirect.com/science/arti cle/pii/S2212567116302660?via\%3Dihub

[7] Hofman-Kohlmeyer1, M. (2016). CUSTOMER LOYALTY PROGRAM AS A TOOL OF CUSTOMER RETENTION: LITERATURE REVIEW. CBU INTERNATIONAL CONFERENCE ON INNOVATIONS IN SCIENCE AND EDUCATION, (pp. 202-206). Prague, Czech Republic

[8] Mathur, D. D. (2015). INFLUENCE OF CUSTOMER LOYALTY PROGRAMMES. INTERNATIONAL RESEARCH JOURNAL OF MANAGEMENT AND COMMERCE , 116.

[9] Mayor, S. (2018). Impact of Customer Loyalty Program to Customer Retention with Special Reference to Jet Airways. International Journal of Innovative Science and Research Technology , 380-404

[10] Zakaria, I., Rahman, B. A., Othman, A. K., Yunus, N. A., Dzulkipli, M. R., \& Osman, M. A. (2014). The Relationship between Loyalty Program, Customer Satisfaction and Customer Loyalty in Retail Industry: A Case Study . Procedia Social and Behavioral Sciences, 23-30

[11] Gupta, R., \& Srinivasan, A. (2019). Loyalty Programs and Their Importance. International Journal of Science and Research, 217-220

[12] Gomez, B. G., Arranz, A. G., \& Cillan, J. G. (2006). The role of loyalty programs in behavioral and affective loyalty. Journal of Consumer Marketing, 387-396. 